\title{
Social Enterprises in the Canadian West
}

\author{
Peter R. Elson \\ Mount Royal University \& University of Victoria \\ Peter Hall \\ Simon Fraser University \\ Sarah Leeson-Klym \& Darcy Penner \\ Canadian CED Network \\ Jill Andres \\ Mount Royal University
}

\begin{abstract}
Western Canada has been the source of significant developments in the social enterprise sector over the past fifteen years. Among these developments one must include the formation of Enterprising Non-Profits in British Columbia, the Social Enterprise Fund in Alberta, and the Canadian CED Network in Manitoba. Underlying these more recent developments is a history of co-operative development and earned revenues by nonprofit organizations, reflecting a longstanding blend of entrepreneurship and community solidarity. This article highlights some of the more recent social enterprise developments in three Western provinces, profiling three independent cases that reflect the diversity of social enterprise activity in British Columbia, Alberta, and Manitoba, and providing the results of social enterprise sector surveys that took place in these same provinces in 2014.
\end{abstract}

\section{RÉSUMÉ}

Depuis quinze ans, l'Ouest canadien a été la source de développements importants dans le secteur de l'entreprise sociale. Parmi ces développements, il faut inclure la formation: d'Enterprising Non-Profits en 


\section{Elson, Hall, Lesson-Klym, Penner, \& Andres (2015)}

Colombie-Britannique; du Social Enterprise Fund en Alberta; et du Réseau canadien de DÉC au Manitoba. Sous-tendant ces progrès récents est une longue histoire de développements coopératifs et de revenus gagnés par des organismes sans but lucratif reflétant une combinaison d'entreprenariat et de solidarité communautaire. Cet article souligne certains des développements plus récents en entreprise sociale dans trois provinces de I'Ouest, recensant trois cas distincts qui reflètent la diversité des activités en entreprise sociale en ColombieBritannique, en Alberta et au Manitoba, et présentant les résultats de sondages sur le secteur de l'entreprise sociale effectués dans ces trois provinces en 2014.

KEYWORDS I MOTS CLES: Social enterprise; Canadian West; Social enterprise sector survey I Entreprise sociale; Ouest canadien; Sondage sur le secteur de l'entreprise sociale

\section{INTRODUCTION}

Western Canada is home to 30 percent of Canadians; it is Canada's gateway to Asia, contains vast stocks of natural resources, and has thriving urban areas. Western Canada has a population that is, on average, younger than the rest of Canada; and is a region that continues to grow, both in diversity and overall population (Roach, 2006). Two-thirds of Canada's First Nations people live in the west; they are an important presence in large urban cities and in many northern and remote communities. According to the 2011 census, the four Western Canada provinces have a population of more than 10.7 million-greater than Atlantic Canada and Québec combined (Statistics Canada, 2012). Between 2006 and 2011, five of the top six metropolitan areas in terms of growth rate were in Western Canada: Calgary, Edmonton, Saskatoon, Kelowna, and Vancouver. There has never been substantial manufacturing in Canada's West nor a robust welfare state-despite Saskatchewan being the birthplace of public healthcare in Canada (Curtis, 2005; Sonpal-Valias \& Sigurdson, 2015; Strikwerda, 2014). Notwithstanding the size of the agricultural industry, what dominates Canada's West are resource extraction-driven economies.

This is the broader context in which nonprofit social enterprises operate in Western Canada; the challenges facing communities have less to do with deindustrialization, and more to do with the cyclical vagaries of the resource industry-social infrastructure and housing shortages in the boom, unemployment and outmigration in the bust cycle. This kind of economy creates a highly fragmented and shifting landscape of want and plenty, and a resulting complex mosaic of social needs. As in other parts of Canada, social enterprise is being explored as one response to meeting these needs by leaders with strong roots in community economic development and a desire for social and economic justice.

This article profiles recent social enterprise developments in three of the four Prairie Provinces. (Survey and case study data for Saskatchewan social enterprises are not yet available.) It discusses the overall scale and scope of social enterprises through a partial comparative analysis of their impact in Western Canada, combined with selected case profiles. These provincial profiles are based on two primary sources of data. The first is the result of social enterprise sector surveys across the three provinces taken between 2010 and 2014. The second is a series of case studies designed to highlight the diversity of social enterprise activity in Western Canada. 


\section{Elson, Hall, Lesson-Klym, Penner, \& Andres (2015)}

\section{CASE STUDIES}

The case studies, our contribution to the larger International Comparative Social Enterprise Models (ICSEM) Project, use a definition of social enterprise that blends societal purpose and market engagement, independent of organizational form (broad definition); and are independent of the social enterprise sector surveys profiled here (Brouard \& McMurtry, 2015). For the social enterprise sector survey research, social enterprise is narrowly defined, as does Enterprising Non-Profits Canada (enp Canada), as a business venture owned or operated by a nonprofit organization that sells goods or provides services in the market for the purpose of creating a blended return on investment, both financial and social/environmental/cultural (Elson \& Hall, 2012).

We prepared a profile of three social enterprises, one in each of British Columbia, Alberta, and Manitoba. These cases were chosen (see Table 1) to highlight social enterprises that are both unique to Western Canada and its First Nations communities, while remaining reflective of the broad definition of social enterprise above. These cases represent a diversity of initiatives that are in different stages of development and that reflect a clear and focused blend of purpose and market. We start our profile in the west and move eastward (in a most unCanadian way!).

Table 1: Summary of case studies in British Columbia, Alberta, and Manitoba

\begin{tabular}{|l|l|l|l|l|l|}
\hline \multicolumn{1}{|c|}{$\begin{array}{l}\text { Name of the } \\
\text { organization }\end{array}$} & \multicolumn{1}{|c|}{ Region/city } & \multicolumn{1}{|c|}{$\begin{array}{c}\text { Legal } \\
\text { structure }\end{array}$} & Ownership & \multicolumn{1}{|c|}{ Purpose } & \multicolumn{1}{|c|}{ Activities } \\
\hline KUTERRA LP & $\begin{array}{l}\text { North Vancouver } \\
\text { Island/Namgis } \\
\text { First Nation }\end{array}$ & $\begin{array}{l}\text { Limited } \\
\text { partnership }\end{array}$ & $\begin{array}{l}\text { Namgis First } \\
\text { Nation }\end{array}$ & $\begin{array}{l}\text { Economic } \\
\text { development and } \\
\text { environ-mental } \\
\text { protection }\end{array}$ & $\begin{array}{l}\text { Commercial land-based } \\
\text { salmon aquaculture }\end{array}$ \\
\hline $\begin{array}{l}\text { Vecova Centre for } \\
\text { Disability Services } \\
\text { and Research }\end{array}$ & $\begin{array}{l}\text { Southern } \\
\text { Alberta/Calgary }\end{array}$ & $\begin{array}{l}\text { Nonprofit } \\
\text { corporation }\end{array}$ & $\begin{array}{l}\text { Stakeholders in } \\
\text { trust (trustees)- } \\
\text { nonprofit } \\
\text { foundation }\end{array}$ & $\begin{array}{l}\text { Workforce } \\
\text { integration for } \\
\text { people with a } \\
\text { disability and/or } \\
\text { community } \\
\text { inclusiveness }\end{array}$ & $\begin{array}{l}\text { A beverage container } \\
\text { recycling depot, recreation } \\
\text { centre, beverage container } \\
\text { pick-up service, baggage } \\
\text { cart retrieval service, and } \\
\text { paper recycling contracts }\end{array}$ \\
\hline $\begin{array}{l}\text { Neechi Foods Co- } \\
\text { op Ltd. }\end{array}$ & $\begin{array}{l}\text { Winnipeg's North } \\
\text { End }\end{array}$ & $\begin{array}{l}\text { Worker- } \\
\text { owned co- } \\
\text { operative }\end{array}$ & Neechi workers & $\begin{array}{l}\text { Provision of quality } \\
\text { products and } \\
\text { services, building a } \\
\text { strong co- } \\
\text { operative, } \\
\text { promoting } \\
\text { community } \\
\text { economic } \\
\text { development, and } \\
\text { opportunities for } \\
\text { Aboriginal people }\end{array}$ & $\begin{array}{l}\text { A full-range grocery section, } \\
\text { fuit and vegetable } \\
\text { courtyard, cafeteria, } \\
\text { restaurant, bakery, fish } \\
\text { market, specialty foods, } \\
\text { Aboriginal books, arts, } \\
\text { crafts, and music, seasonal } \\
\text { farmers market, hardware, } \\
\text { and dry goods }\end{array}$ \\
\hline
\end{tabular}

\section{BC: A LEADER IN THE SOCIAL ENTERPRISE MOVEMENT}

Enterprising Non-Profits (enp) - now known as enp BC-has been a guiding light for social enterprise in Canada (enp Canada, 2015a). Enp BC started in 1997 with a pilot project led by Vancity Community Foundation in 


\section{Elson, Hall, Lesson-Klym, Penner, \& Andres (2015)}

collaboration with the Vancouver Foundation and the United Way of the Lower Mainland (enp Canada, 2015a). With hindsight, neither the timing (in the aftermath of the federal budget cuts begun in the 1995 Martin budget) nor the location (in a province that had long embraced mixed public-private-community modes of social service delivery) of this launch are surprising. With additional funding from the McConnell Foundation, the project was initially designed to help ten nonprofits become more self-sustainable by developing social enterprises. From these small beginnings enp BC evolved to launch an Enterprising Non-Profits website and compile resources and tools to assist social enterprises across Canada. In 2006, for example, enp BC published the Canadian Social Enterprise Guide-the first of its kind to focus on social enterprise in a Canadian context (enp Canada, 2015a).

Enp BC now hosts a wide range of supports for social enterprises, from workshops to grants and pitch competitions. The enp BC website contains several toolkits, an online resource library, and a podcast series. Enp $\mathrm{BC}$ also produces an e-newsletter delivered regularly to over 4,000 subscribers across Canada. Enp BC was instrumental in the development of enp Canada and its initiative, Social Enterprise Canada (enp Canada, 2015a).

\section{Policy recognition}

The right-leaning BC Liberal government has, after a decade in power, come to acknowledge social enterprise in policy. In 2011 the BC Social Innovation Council was established with a mandate to assist the province in tackling some of its most pervasive social challenges. A 2012 Action Plan to maximize social innovation in British Columbia focused on supporting social enterprise, legislative and regulatory environments, social innovation labs and design processes, engagement, and learning and research (BC Social Innovation Council, 2012). Once the Action Plan was tabled, BC Partners for Social Impact was created to carry on the work of the BC Social Innovation Council. The BC government co-chairs the BC Partners for Social Impact, which now includes more than 70 multi-sector partners who work collaboratively to implement the recommendations and support social innovation (BC Partners for Social Impact, 2015). The BC government has also passed a new corporate structure, the Community Contribution Company legislation, similar to the UK, with partial asset lock provisions and related regulations (British Columbia, 2013). Although the take-up with this new corporate form has been nominal to date, British Columbia is the only jurisdiction in Canada that has established regulations for such a form of incorporation.

In 2014, the provincial government proclaimed April "Social Enterprise Month" to celebrate the growing social enterprise sector and recognize its contribution to the strength and resiliency of $\mathrm{BC}$ communities. This exposure has been substantiated with a number of ancillary efforts. The University of British Columbia has partnered with Coast Capital Savings, a credit union, to create a Social Innovation Hub to accelerate social venture growth. Simon Fraser University has launched RADical Ideas, Useful to Society (RADIUS), an innovation lab and incubator, and the University of Victoria has established a new Innovation Centre for Entrepreneurs (ICE).

The policy trajectory described here suggests a subtle but persistent change. The initial efforts had more of a focus on community development and social service delivery; and this is still a core component of the enp BC approach. However, most of the initiatives launched since 2010 reflect a shift toward social innovation and finance, with rather less emphasis on the nonprofit origins of social enterprises. It is still too early to say what the implications of this shift will be. 


\section{Elson, Hall, Lesson-Klym, Penner, \& Andres (2015)}

\section{CASE ONE (BC)}

\section{'Namgis First Nation, British Columbia}

An indigenous First Nation transformed its concerns about the effects of open net-pen salmon aquaculture into a social enterprise that has the potential to catalyze a more sustainable aquaculture industry in Canada.

\section{Context}

The wild Pacific salmon that live just off the west coast of mainland British Columbia and around Vancouver Island are intricately connected to the environmental well-being of the province. However, this well-being may be threatened by a practice referred to as open net-pen/open net-cage salmon farming, wherein Atlantic salmon are grown in densely populated nets, often located on the out-migration routes of the wild Pacific salmon. "Waste, chemicals, disease, and parasites from the farms pass through the mesh [nets] and pollute the surrounding water and seabed. Especially harmful are the sea lice who attach to wild juvenile salmon on their migration out to sea" (Living Oceans, 2015, n.p.). An alternative to the practice of open net-pen salmon farming is land-based closed containment (LBCC) aquaculture. LBCC introduces a barrier between the farmed salmon and the marine environment, which eliminates the risks to the wild salmon, while maintaining the levels of salmon produced as a food source.

The 'Namgis First Nation is situated in an area of northern Vancouver Island where a large number of these open net-pen Atlantic salmon farms are located. Growing concerns about the negative impact of these farms on the marine environment motivated the 'Namgis to explore alternatives to this unsustainable practice. Eric Hobson, an entrepreneur, philanthropist, and avid fisherman, shared the 'Namgis concerns, and founded Save Our Salmon Marine Conservation Foundation (SOS) in 2007 to begin to address this multifaceted issue through scientific research and policy advocacy. Eric Hobson and Bill Cranmer, then chief of the 'Namgis First Nation, had both been exploring LBCC aquaculture and could see the potential for significant environmental, social, and economic benefits. However, at that time, there were no commercial-scale LBCC salmon farms in Canada and the viability of such an undertaking was unknown.

\section{KUTERRA LP}

In 2011, after consultation with 'Namgis First Nation members, the 'Namgis chief and council created KUTERRA LP (KUTERRA), a social enterprise wholly owned by the 'Namgis First Nation and situated on 'Namgis land. "KUTALA means salmon in the language of the 'Namgis people. TERRA means land. And KUTERRA means salmon from the land" (Kuterra, 2014). While this case does not fit the above definition of a social enterprise, which was used for the purpose of conducting the survey, these case studies were conducted independently of the surveys and are presented here as a reflection of the diversity of organizational forms social enterprises take in Western Canada.

KUTERRA was formed for the dual purpose of:

1. Testing the technical, biological, and economic feasibility of producing Atlantic salmon at commercial scale using a land-based closed containment recirculating aquaculture system (RAS); and

2. Creating economic benefits for the 'Namgis community, such as jobs and training opportunities in this important new technology for First Nations members. 


\section{Elson, Hall, Lesson-Klym, Penner, \& Andres (2015)}

KUTERRA benefits from the involvement of project partner SOS, which provides business expertise. The project also benefits from the involvement of Tides Canada, which provides funding through the Salmon Aquaculture Innovation Fund, technical support through the Conservation Fund's Freshwater Institute, and independent environmental monitoring through the Pacific Salmon Foundation. Other funding has been provided by Sustainable Development Technology Canada and the 'Namgis First Nation itself. Finally, KUTERRA's board and advisory team include financial, legal, engineering, and industry experts from across North America.

In March 2013, KUTERRA began operations as the first Canadian LBCC farm to "demonstrate the commercial viability of producing Atlantic salmon for table food in a land-based, closed containment recirculating aquaculture system (RAS)" (Kuterra, 2014, n.p.). One year later, on Earth Day (April 22) 2014, KUTERRA salmon officially entered the marketplace and is now distributed through Albion Fisheries, and sold to consumers through Safeway stores in British Columbia and Alberta.

KUTERRA is growing Atlantic salmon, in order to be able to directly compare and assess the viability of an alternative aquaculture industry to that which produces Atlantic salmon in open net-pens. To support the goal of growing a sustainable aquaculture industry, performance metrics related to production costs and biological and technical assumptions related to the KUTERRA Project are being tracked and will be widely disseminated to help drive the growth and development of this industry.

While these are still early days for KUTERRA, utilization of the facility's full stocking density is projected for early 2015, and positive cash flows are projected for the end of the 2015 fiscal year. Finally, there is an expectation that several ancillary businesses such as aquaponics, value-added processes such as custom smoking, and energy production from the anaerobic digestion of the solid waste, will follow this initial phase of KUTERRA and result in further environmental and economic benefits.

\section{ALBERTA: SOCIAL ENTERPRISE AND THE NEW WEST}

The social enterprise sector in Alberta does not share the history of sector-wide developmental funding that enp represents in BC. However, there are a number of significant and worthwhile initiatives that have been undertaken to support social enterprises in Alberta. Among them are the Alberta Community and Co-operative Association's Unleashing Local Capital project (initiated in 2012); the Calgary-based community economic development networking organization Thrive (founded in 2006); the Social Enterprise Fund, launched in 2008 by the Edmonton Community Foundation and the City of Edmonton; the Trico Charitable Foundation (also launched in 2008); and the Calgary Foundation Social Enterprise Initiative (launched in 2011). In 2013 Calgary hosted the Social Enterprise World Forum, attracting more than a thousand delegates from all corners of the globe. The Trico Charitable Foundation is an enp Canada affiliate (enp AB) and as such provides workshops, a grant program, and pitches contests to foster social enterprises throughout the province, as do the enp affiliates in British Columbia, Manitoba, Ontario, and Nova Scotia (enp Canada, 2015a).

The Social Enterprise Fund (SEF) is a loan fund representing a direct social asset investment, not a grant program, by the Edmonton Community Foundation. The SEF plays a role in the larger community interested in the concept of social enterprise, working with partners across the province and the country to expand the practical understanding of how social enterprise works "on the ground," as well as contributing to the training 


\section{Elson, Hall, Lesson-Klym, Penner, \& Andres (2015)}

opportunities available to social entrepreneurs (Social Enterprise Fund, 2015b). The SEF has recently partnered with Calgary's enp $A B$ to present learning and workshop opportunities for those interested in social enterprise (Social Enterprise Fund, 2015a).

Social enterprise has also been a focus area for the Calgary Foundation's community leadership program. The first phase was a research initiative that resulted in a report, "Mission and Money," jointly funded by the Calgary Foundation, United Way of Calgary and Area, and the City of Calgary, which validated the appetite among nonprofit organizations and social investors for social enterprise (Calgary Foundation, 2011b). This was followed by a pilot project, in partnership with Social Venture Partners Calgary, to study the growth of social enterprises through a comprehensive case study analysis (Calgary Foundation, 2011a). Other exploratory studies have been undertaken by community groups such as the United Way of Calgary and Area (United Way of Calgary and Area, 2014).

Pilot and catalytic programs, rather than a substantive and co-ordinated social enterprise development strategy, has occurred in Alberta; none more visible than the 2014 announcement and subsequent cancellation of a $\$ 1$ billion Provincial Social Innovation Endowment Fund (Alberta, 2015). There is substantial potential for social enterprise development in Alberta. The requisite mind-set appears to be there, and there are a number of groups, both in the provincial government and in communities, particularly Calgary and Edmonton, that are exploring the implications of the broader concept of social innovation through an evolving Alberta Social Innovation Network. Only time will tell if these largely independent initiatives will spark a broader social enterprise movement across the province.

\section{CASE TWO (AB)}

\section{Vecova Centre for Disability Services and Research, Calgary, Alberta}

With five social enterprises that offer tangible examples of inclusive community, Vecova reflects a balance of staying power and ongoing innovation.

\section{Context}

Vecova Centre for Disability Services and Research (Vecova) provides a range of supports and services for individuals with developmental disabilities and diverse needs. The organization also produces accessible, practical research as an affiliate research institute of the University of Calgary. A volunteer board of directors comprised of ten community and rehabilitation industry leaders governs Vecova.

Since its inception in 1969, Vecova has operated a number of enterprises aimed at providing training and employment for people with developmental disabilities. Over the years, Vecova has housed a commercial kitchen and a cafeteria, a garage and a gas station, and even a greenhouse. The "sheltered workshop" approach, which was part of Vecova's early years when people with disabilities were employed separately from the rest of the working population, has been entirely replaced with social enterprises that have integration and inclusiveness at their core. In 2013, Vecova's social enterprises provided a total of 56 jobs for people with disabilities. The type of disability employees live with varies, but is primarily developmental disabilities.

Social enterprise is part of Vecova's culture and is considered integral to the organization. All four of the current social enterprises are expressions of Vecova's mission and have emerged organically from within the 


\section{Elson, Hall, Lesson-Klym, Penner, \& Andres (2015)}

organization. These financially self-sustaining social enterprises also further Vecova's mission through contributions of surplus revenue to shared organizational costs. Sales make up 16 percent of Vecova's revenue, and are the second largest financial contributor to the organization after government contracts (76 percent). Any operational shortfalls are addressed through fundraising. The recreation centre and the baggage cart service are profitable, the paper recycling contract breaks even, the pick-up service is brand new so will require some time to break even, and the bottle depot had a small shortfall in 2013.

\section{Vecova's social enterprises}

With a portfolio of social enterprises that spans more than three decades, Vecova has become the oftreferenced archetype for social enterprise in the Calgary area. Vecova operates five social enterprises:

1. Beverage Container Recycling Depot (Bottle Depot): Calgary's only nonprofit bottle depot, it has processed over 14 million containers to date;

2. Recreation Centre: The recreation centre, a fully accessible facility, brings the community to Vecova to participate in fitness and recreational activities;

3. Baggage Cart Retrieval Service (Baggage Cart Service): The airport baggage cart service is Vecova's third example of a business that can operate profitably with an integrated workforce;

4. Beverage Container Pick-Up (Pick-Up Service): A free bottle pick-up service that diverts recycling from the landfill and creates jobs for people with disabilities; and

5. University of Calgary $(U$ of $\mathrm{C})$ Recycling: A contract to gather paper recycling at various locations across campus, which provides highly flexible work for people with disabilities.

\section{Bottle Depot}

The bottle depot has evolved well beyond its roots as a sheltered workshop and now serves to demonstrate to the rest of the business community that it is entirely feasible to operate a sustainable business with an integrated workforce that includes people with disabilities. To support this core purpose, Vecova does not subsidize wages or employ other practices that would differentiate the depot from its competitors. Employees with special needs are just that: engaged employees-not passive clients-and the bottle depot has been able to demonstrate its ability to successfully compete with other depots in the city. In 2013, 75 percent of the hours worked in the depot were by people with developmental disabilities. In terms of severity of disability, employees need to be able to complete their jobs reasonably independently.

Vecova's focus on systems and processes to drive volume is critical to its success in the highly regulated beverage container recycling industry. With strong business practices as its foundation, Vecova is able to leverage its charitable status as a competitive advantage.

Although many other depots across Calgary accept donations of beverage containers and direct the proceeds to charity, when Vecova accepts donations, the proceeds are directed toward supporting Vecova's mission. Thus when people donate their cans, they forego their deposit return and this money goes to Vecova to fund its operations. Ann-Marie Latoski, director of social enterprise at Vecova, describes the social mission as a draw for customers. "Some people are very loyal to us because they know we employ and support people with disabilities. So they will drive to come to our depot" (Latoski, personal communication, 2012). 


\section{Elson, Hall, Lesson-Klym, Penner, \& Andres (2015)}

\section{Recreation Centre}

The recreation centre also has a lengthy history with Vecova. From the outset, Vecova's recreation centre has been offering recreational and therapeutic programs for people with disabilities. Early on, Vecova perceived an opportunity to expand the mandate of the recreation centre, and by the early 1980s the centre was completely open to the public. This expanded mandate has served a dual function for the organization: furthering Vecova's social mission and bolstering the financial viability of the recreation centre.

Like the bottle depot, the recreation centre also leverages Vecova's social mission and charitable status. However, as in the case of the bottle depot, sound business practices are critical in an industry that has tremendously high staffing and facility maintenance costs. Therefore, Vecova's board and senior leadership team must be comfortable making investments that have traditionally been difficult for charities to make, including making expenditures on the necessary facility upgrades and extra staffing required for a recreation centre to be successful.

Marketing has also been critical in recent years, particularly to attract segments of the population that were originally overlooked. The warm pool, used primarily for recreational and therapeutic programs for people with disabilities, also appeals to another, previously untapped customer segment: mothers and babies. Since implementation, programs for this segment have filled up rapidly and are rarely without a waiting list.

Higher margin opportunities exist in the form of facility rentals. There are five larger organizations that run their operations permanently out of Vecova's facility, while approximately 25 smaller groups rent space on a more casual basis.

\section{Baggage Cart Service}

The Calgary Airport Authority baggage cart service contract, which is now over fifteen years old, is Vecova's third social enterprise. In fact, it was a customer of the bottle depot who understood Vecova's inclusive approach to employment who suggested that the organization bid on the airport contract. Vecova submitted a proposal and won the ten-year contract in an open competition. A decade later, when the Calgary Airport Authority again invited tenders for the contract, Vecova was the successful bidder for an additional ten-year term.

\section{Pick-Up Service}

The most recent addition to Vecova's social enterprise portfolio is a beverage container pick-up service, which launched in 2013. Upon sign up residential and corporate customers are ouffitted with bags and a bin, and for every full bag they recycle, customers receive a $\$ 16$ tax receipt. The program has grown rapidly to over 3,300 subscribers.

\section{University of Calgary Recycling}

The contract for paper recycling at the University of Calgary began in 1997 as a collaboration between Vecova and other agencies working with people with disabilities. Over the years, the other agencies gradually withdrew from the work, leaving Vecova as the sole contractor. Concurrently, the number of buildings at the University of Calgary that Vecova was servicing gradually increased without a corresponding update in the terms of the contract.

In part, the focus on the social side of the contract (the employment opportunities) rather than the business arrangement was a product of the work being organized as part of client services at Vecova. The focus of Vecova's services is to provide supports in all areas of daily living, including employment, such that people with 


\section{Elson, Hall, Lesson-Klym, Penner, \& Andres (2015)}

disabilities can live the life they choose. Therefore, it made sense for the contract to reside in this part of the organization-except for the fact that this arrangement with the University of Calgary held greater potential to further Vecova's mission if it was managed more as a social enterprise with a dual focus on the financial, as well as the social, outcomes. As a result, in the spring of 2014, the Vecova clients working on this contract were hired as employees of Vecova and the contract itself is being renegotiated.

\section{ON THE MOVE: SOCIAL ENTERPRISES IN MANITOBA}

Manitoba's social enterprises, like those in $B C$ and Alberta, do not exist in a vacuum. Their success (or failure) hinges not only on social needs and market opportunities, but also on the ecosystem of community and government supports around them. The fall of 2013 saw the Manitoba office of the Canadian Community Economic Development Network (CCEDNet - Manitoba) bring together the Social Enterprise Working Group-a group of over 30 social enterprise practitioners and developers-to discuss the opportunities and challenges facing the sector in Manitoba. This conversation reiterated that many social enterprises were facing similar challenges, and reinforced the need for a co-ordinated response to creating a strong ecosystem for social enterprise development.

\section{Government support}

The Manitoba government has strengthened the social enterprise sector by implementing progressive legislation and by removing certain financial barriers to social enterprise development. Until recently this support has mostly been ad hoc and reactive. However, CCEDNet - Manitoba found common ground with the province's interest in supporting the creation of 75,000 jobs by 2020, which led to a commitment in the 2014 budget toward the creation of a jointly constructed strategy to enhance the social enterprise sector (Howard, 2014). Social enterprises that provide job and training opportunities for people with barriers to employment present the province with a unique opportunity to access and develop labour markets that are particularly underserved, while making fiscally sound investments in reducing poverty (Government of Manitoba \& CCEDNet, 2015).

The co-created Manitoba Social Enterprise Strategy, released in February 2015, outlines recommended action steps and comparative in- and out-of-province initiatives focusing on six pillars of social enterprise development: enhancing entrepreneurial skills; ensuring access to capital and investment; expanding market opportunities; promoting and demonstrating the value of social enterprise; improving regulatory frameworks; and creating networks and community engagement (Government of Manitoba \& CCEDNet, 2015). Responding to a policy resolution clearly outlined by CCEDNet - Manitoba, the strategy uniquely positions Manitoba as a leader and champion in job creation through social enterprise development by ensuring that the policy environment is not creating barriers to social enterprise operations, but is in fact enabling them to achieve their missions (Elson, Hall, Leeson-Klym, Penner, \& Wamucii, 2015, in press).

Other provincial initiatives include the creation of financing mechanisms and support for social enterprise solutions to food insecurity. By committing over half a million dollars to social enterprise development in northern communities, the province is enabling social enterprise as an effective way to address multiple social determinants of community health such as unemployment, food insecurity, and poverty (Howard, 2014). Measures such as the Community Economic Development Tax Credit, the Neighbourhoods Alive! Tax Credit, and the Employee Share Purchase Tax Credit provide tools to improve financing options for a variety of 


\section{Elson, Hall, Lesson-Klym, Penner, \& Andres (2015)}

community economic development initiatives that support social and economic opportunities in communities across Manitoba (Elson et al., 2015).

\section{Community support}

In addition to this enabling political environment, social enterprises in Manitoba have benefited from the aid of diverse support organizations across the province. CCEDNet-Manitoba has been a catalyst for creating a supportive political environment and a convening body to work toward co-ordinating the system of supports. This work has educated governments regarding the advantages of policies that encourage the sustainability and growth of social enterprises.

CCEDNet - Manitoba convenes the sector, promotes the successes of social enterprise, and builds capacity within organizations and practitioners. CCEDNet - Manitoba's research activities engage the social enterprise sector through consultation to identify needs, challenges, and potential for growth. As the Manitoban affiliate for enp Canada, CCEDNet has hosted five Build and Grow Your Social Enterprise workshops and awarded over $\$ 99,000$ in Social Enterprise Development Grants. Administering the enp MB program has allowed CCEDNet Manitoba to leverage key resources from a number of important social enterprise sector leaders to begin creating a comprehensive system of support for new and developing social enterprises in Manitoba (enp Canada, 2015b).

Other important ecosystem supports for social enterprise include, but are not limited to, Supporting Employment and Economic Development (SEED) Winnipeg, Local Investment Toward Employment (LITE), Assiniboine Credit Union, and the Jubilee Fund. Groups like these build social enterprise capacity, fundraise, finance, and provide grants to social enterprises as well as contributing to overall sector development through the Social Enterprise Working Group and CCEDNet. For example, since the early 1990s, SEED Winnipeg has engaged in business development and the promotion of local social enterprises and worker co-operatives to pursue its mandate "to combat poverty and promote inner-city renewal through micro and community enterprise development for low income people" (Loxley \& Simpson, 2007, p. 24).

LITE has conducted public awareness and education campaigns and programs, and raised community funds to catalyze new social enterprise opportunities. In 2011, LITE adopted the Winnipeg Social Purchasing Portal, first established by SEED Winnipeg, which connects individual and institutional purchasers with social enterprises across the city through an online database. Numerous sectoral associations also provide development support and assistance, including the Manitoba Cooperative Association, the Farmers' Markets Association of Manitoba, the Manitoba Arts Council, the Manitoba Child Care Association, and many others.

\section{CASE THREE (MB)}

\section{Neechi Foods Co-operative Ltd., Winnipeg, Manitoba}

Neechi Commons, one of two locations developed by Neechi Foods Co-op Ltd., is a 25,000-square-foot building that is home to various food-related entities and an art store/gallery with an Aboriginal and local/regional focus. Neechi actually means friend, sister, or brother in Ojibway and Cree (Simard, 2010). Opened in 2013, the Commons expands the vision of Neechi Foods Co-operative Ltd., which began 26 years ago and previously operated a grocery store. It is one of the few Aboriginal-led worker co-ops in Canada, elevating personal and social healing through economic empowerment. The co-op's member workers gain skills and knowledge with training and employment while generating economic opportunities for local producers of goods and services as 


\section{Elson, Hall, Lesson-Klym, Penner, \& Andres (2015)}

well as community enrichment (Bailey, 2015). On Louis Riel Day 2015, February 16, Neechi Foods Co-op Ltd. was honoured by Heritage Winnipeg with its 2015 Special President's Award for the heritage restoration work that went into the creation of Neechi Commons. In 2013 Neechi Foods Co-op Ltd. was the winner of the Excellence in Aboriginal Business Leadership Award from the Asper School of Business at the University of Manitoba (Neechi Commons, 2015b)

Neechi Foods Co-op Ltd. is committed to providing quality products and services, to building a strong cooperative, and to promoting community economic development and opportunities for Aboriginal people (Neechi Commons, 2015b). Neechi sells freshly prepared bannock, wild rice, wild blueberries, freshwater fish, and other Indigenous specialty foods, "homemade" deli products, conventional grocery items, and Aboriginal crafts, books, and music (coopzone, 2011).

Neechi Foods is incorporated as a worker co-operative under the Cooperatives Act of Manitoba. Its membership consists of its staff members, who are each required to hold a member share. Neechi uses the worker ownership business structure to promote a sense of business ownership among the employees and, in turn, to enhance productivity. There are currently 37 full-time staff members, eight part-time (less than 30 hours a week), three full-time volunteers, and one part-time volunteer. The worker co-operative model also favours a strong sense of community identity and responsibility. The co-op has a seven-member board of directors (coopzone, 2011).

Neechi Commons also strives to revitalize commerce in the economically challenged Winnipeg neighbourhood in which it chose to locate. Neechi is the largest commercial employer of Aboriginal people in Winnipeg, which is home to the largest urban Aboriginal population in Canada, or about 75,000 people. The co-op has created upwards of 50 new employment opportunities for Aboriginal youth and other residents of the neighbourhood (Bailey, 2015).

Its work is based on a number of principles, from creating and purchasing locally sourced and produced goods and local reinvestment of surpluses to community-oriented business ownership and creating healthy, sustainable communities. "It brings hope of a different way to organizing economic life that seems to work better in many cases in the Aboriginal community," says Hazel Corcoran, executive director of the Canadian Worker Co-operative Federation, of which the Neechi co-op is an original member (Bailey, 2015, p. 15).

Neechi Commons is not all about food. The "Commons" also hosts the Aboriginal Chamber of Commerce, the Momentum Centre, which helps to transition Aboriginal youth and new Canadians aged 18 to 30 years off employment and income assistance into careers of their choice, as well as numerous community events. Neechi facilitates the learning of hard skills as well as traditional artisan skills, and is both a showcase and source for local and Aboriginal goods and services.

Neechi's transition to the larger, more diversified Neechi Commons from its former smaller space has raised the spectre of balancing the management of operations and finances with the inadequate resources available. Challenges during the construction phase of the new space left the co-op carrying excessive debt and lacking the working capital needed to hire the anticipated staff and to fully develop the business according to plan. This led the Canadian Worker Co-operative Federation to create the Neechi Support Committee, which is helping to source new capital, including grant funding for social enterprises, and to implement plans. Table 2 is a current list of the community and retail services provided by Neechi Commons. 
Elson, Hall, Lesson-Klym, Penner, \& Andres (2015)

\section{Table 2: Neechi Commons community and retail services}

\begin{tabular}{|ccc|}
\hline $\begin{array}{c}\text { Neechi Niche Arts Store and } \\
\text { Gallery }\end{array}$ & Momentum Centre & Staff development program \\
Seasonal farmers' market & Aboriginal Arts Centre & Three Sisters Fruit and Vegetable Courtyard \\
Aboriginal Chamber of Commerce & Come N' Eat Restaurant & Kookum's Bakery \\
Supermarket & Neechi Foods Co-op & \\
\hline
\end{tabular}

Neechi hopes to launch an investment share offering (ISO) soon, and it will include a tax credit to Manitobans who invest (Neechi Commons, 2015a). If approved, this would be the second ISO offered by Neechi Foods Coop Ltd.; the first, in 2012 supported the Commons initiative (Bailey, 2015; Neechi Commons, 2015a).

\section{Comparative developments}

Beyond these case studies, distinctive provincial policy, and programmatic histories, what is the collective impact of social enterprises beyond the micro scale? At a provincial level, a different, yet equally interesting picture starts to emerge. To draw such a picture, the only known progressive, systematic, and multiyear survey of social enterprises at a provincial/state level has been underway since 2010, to be concluded at the end of 2015. Across three Western provinces, surveys have been undertaken three times in BC and Alberta (2010, 2012, 2014) and twice in Manitoba $(2012,2014)$. The surveys have included nonprofit agricultural societies, farmers' markets, thrift stores, museums and galleries, employment and training, and recycling social enterprises. All surveys were conducted by the invitation of and in collaboration with provincial social enterprise partners. All surveys and related reports to date are available at the Social Enterprise Sector Survey website (www.sess.ca). What we present here is a detailed profile of the latest (2014) survey results and some observations for BC, Alberta, and Manitoba.

\section{Limitations}

In conducting provincial social enterprise sector surveys over the last five years, we have resisted an exclusively numerical or statistical comparison of social enterprises for three reasons. First, we are only too aware that our knowledge of the collective impact of social enterprises is in its infancy and, while we have had an excellent response as shown below in Table 3, the results only speak to the impact of the social enterprises that responded to the survey, and not the social enterprise sector as a whole. Both resources and time limited our capacity to identify all social enterprises, although a substantial majority (in excess of 80 percent) of social enterprises within any one category was identified (e.g., thrift stores, farmers' markets). The response rate, although excellent for a survey of this type (ranging from 21.9 percent in BC, 30.5 percent in Alberta, to 41.0 percent in Manitoba), does not allow us to predict what the remaining non-responding social enterprises would have reported, had they done so. Second, not all responding social enterprises provided complete financial data and our financial analysis was restricted to those that did.

Third, we now appreciate the tremendous contextual variations that exist across provinces and territories, and often within these regions (e.g., core urban/suburban/rural, French/English). These contextual differences should not be dissociated from the quantitative analysis; they may be geographic or linguistic, but they are also 


\section{Elson, Hall, Lesson-Klym, Penner, \& Andres (2015)}

historic and economic, cultural and political. The complexity of this level of analysis is beyond the scope of this article, but the profiles of developments in British Columbia, Alberta, and Manitoba are designed to make this point.

That being said, there are some comparative statistical highlights we would like to draw to your attention (see Table 3).

\section{Statistical highlights}

First, there are more new social enterprise respondents in British Columbia than was the case in the previous provincial survey in 2012. The timing of the median age of social enterprises (18 years old in 2015) coincides with the formation of Enterprising Non-Profits (enp BC) in 1997. While we cannot determine any strict causal relationship, this speaks to the value of a dedicated social enterprise "hub" to inform and educate practitioners, policy makers, the media, and the general public.

Most social enterprises report that they target multiple population groups (2-6), with an average of over 4 populations. There are indications that some rural social enterprises in the Canadian West share this commitment to serving whole communities; urban-based social enterprises tend to specialize in serving particular population groups, often providing them with meaningful employment. This is significant as it moves a person who historically would be seen as a "passive client of services" to an "engaged employee in service to others." Those employed from a target group average of 21.5 (with range 11.7-35.8) per social enterprise. Half of BC's social enterprises focus on addressing barriers to employment-and also employ target group members at an average of 41 per social enterprise. Alberta is below the reported average on social enterprises that focus on employment, at only 31 percent. However with respect to overall employment, on average, Alberta social enterprises hire more people.

This suggests that there is a qualitative difference in the mix of social enterprises in these two provinces: smaller, employment-intensive social enterprises in British Columbia and larger organizations in Alberta. Thus hiring of target populations in Alberta would appear to be the result of the size of the social enterprise, rather than being an explicit goal. Employment development is the purpose of over 30 percent of BC social enterprises (see Table 3 and training is the focus of 23 percent of $\mathrm{BC}$ social enterprises.

Survey findings across Canada confirm that while earned revenue is an important motivation for establishing social enterprises, relatively few social enterprises exist primarily to generate revenue for their parent organizations. Less than 30 percent of Western Canadian social enterprises indicate that one of their purposes is to generate revenue for a parent organization (e.g., thrift stores, YMCA/YWCA programs), and we would classify only one-tenth as being primarily driven by income generation. While making money is certainly an important dimension of operating a successful social enterprise, by definition this revenue generation is blended with a social, environmental, or cultural purpose.

Note that these "purposes," in this particular analysis, are not mutually exclusive. Almost 80 percent of social enterprises, consistently across all provinces, report that they are engaged in a "social" mission; those engaged in a cultural mission range from 49 percent to 64 percent. Social enterprises with an environmental mission (e.g., recycling) consistently average about 25 percent of social enterprises across all surveyed provinces. More than half of social enterprises are also registered charities, which suggests that retaining the ability to raise revenues through donations and grants from foundations remains an important option for many in the sector. 


\section{Elson, Hall, Lesson-Klym, Penner, \& Andres (2015)}

Who gets served? Almost 65 percent of social enterprises serve everyone in a community. Youth and young adults are targeted by 40 percent of social enterprises, likely due to the prevalence of employment training programs for this population, which experiences unacceptable unemployment rates. More than 25 percent of social enterprises across Canada collectively serve the following target groups: youth, women, seniors, people living with physical disabilities, men, lower-income individuals, families, children, and First Nations/indigenous people.

This almost national-in-scope statistical comparison suggests that across Canada, social enterprises are similar in some structural terms, but further probing will point to particularities at the provincial level, which in turn can mask the truly great diversity of social enterprises. We next highlight key survey results for each of the three surveyed Western provinces.

Table 3: Summary statistics for 2014 social enterprise surveys

\begin{tabular}{|c|c|c|c|}
\hline & $A B$ & $\mathrm{BC}$ & MB \\
\hline \multirow{2}{*}{\multicolumn{4}{|c|}{ Demographic profile }} \\
\hline & & & \\
\hline Year of formation: median & 1984 & 1997 & 1985 \\
\hline Year of first sale: median & 1988 & 2000 & 1988.5 \\
\hline Number of business sectors (1-17): average & 1.7 & 1.9 & 1.9 \\
\hline Number of targeted populations (0-17): average & 4.3 & 5.4 & 4.3 \\
\hline Individual members: average in 2013 & 67.6 & 150.5 & 255.2 \\
\hline Organizational members: average in 2013 & 22.4 & 14.0 & 6.9 \\
\hline Trained: average for 2013 & 464.6 & 43.8 & 88.9 \\
\hline Employed (from target group): average for 2013 & 35.8 & 11.8 & 37.5 \\
\hline Served: average for 2013 & 6916.9 & 8109.4 & 7688.5 \\
\hline Full-time Equivalent employees: average in 2013 & 28.4 & 9.0 & 19.4 \\
\hline Volunteers (full-time and part-time): average in 2013 & 175.6 & 50.0 & 75.2 \\
\hline Total expenditures: \$ average in 2013 & 694,164 & 764,304 & 695,395 \\
\hline Total wages and salaries: \$ average in 2013 & 404,792 & 396,916 & 407,895 \\
\hline Total revenue: \$ average in 2013 & 702,900 & 792,895 & 750,792 \\
\hline Revenue from sales of goods and services: \$ average 2013 & 407,690 & 611,256 & 579,614 \\
\hline $\begin{array}{r}\text { Revenue from grants and donations received from parent organization: } \\
\text { \$ average } 2013\end{array}$ & 17,624 & 28,090 & 6,894 \\
\hline $\begin{array}{r}\text { Revenue from grants and donations from other organizations and private individuals: } \$ \\
\text { average } 2013\end{array}$ & 138,954 & 112,020 & 108,654 \\
\hline Revenue exceeds expenses in 2013: percent & 76.4 & 80.9 & 80.0 \\
\hline Sales as percent of revenue: average per organization 2013 & 46.6 & 60.7 & 57.0 \\
\hline Revenue less grants/loans/donations exceeds expenses in 2013: percent & 34.8 & 33.7 & 28.9 \\
\hline \multicolumn{4}{|l|}{ Purpose (percent of social enterprises): } \\
\hline Employment development & 19.8 & 32.2 & 33.3 \\
\hline Training & 14.9 & 23.1 & 29.7 \\
\hline Income generation for parent organization & 22.8 & 22.3 & 29.7 \\
\hline Social mission & 79.2 & 82.6 & 77.5 \\
\hline Cultural mission & 64.4 & 48.8 & 58.6 \\
\hline Environmental mission & 24.8 & 28.1 & 24.3 \\
\hline \multicolumn{4}{|l|}{ Legal structure (percent of social enterprises): } \\
\hline Nonprofit legal structure & 96.0 & 90.1 & 86.5 \\
\hline
\end{tabular}


Elson, Hall, Lesson-Klym, Penner, \& Andres (2015)

\begin{tabular}{|c|c|c|c|}
\hline & $\overline{A B}$ & $\mathrm{BC}$ & MB \\
\hline Registered charity & 61.0 & 65.5 & 51.8 \\
\hline Co-operative (distributing) & 3.0 & 0 & 1.0 \\
\hline Co-operative (non-distributing) & 4.0 & 2.5 & 9.0 \\
\hline \multicolumn{4}{|l|}{ Target groups (percent of social enterprises): } \\
\hline All the people living in a particular place/community & 73.3 & 65.3 & 63.1 \\
\hline First Nations/indigenous people & 25.7 & 41.3 & 34.2 \\
\hline Children & 47.5 & 40.5 & 25.2 \\
\hline Ethnic minority & 21.8 & 29.8 & 24.3 \\
\hline Families & 42.6 & 37.2 & 25.2 \\
\hline People who are homeless & 8.9 & 20.7 & 11.7 \\
\hline Immigrants & 15.8 & 22.3 & 23.4 \\
\hline Lower-income individuals & 23.8 & 38.8 & 31.5 \\
\hline Men & 29.7 & 33.9 & 28.8 \\
\hline People living with addictions & 8.9 & 22.3 & 13.5 \\
\hline People living with employment barriers & 17.8 & 30.6 & 22.5 \\
\hline People living with psychiatric disabilities & 13.9 & 28.1 & 16.2 \\
\hline People living with intellectual disabilities & 14.9 & 31.4 & 26.1 \\
\hline People living with physical disabilities & 20.8 & 33.1 & 24.3 \\
\hline Refugees & 7.9 & 9.9 & 12.6 \\
\hline Senior/aged/elderly & 41.6 & 37.2 & 33.3 \\
\hline Women & 36.6 & 41.3 & 35.1 \\
\hline Youth/young adults & 49.5 & 43.8 & 36.9 \\
\hline \multicolumn{4}{|l|}{ Sector of products and services sold (percentage) } \\
\hline Resources, production, construction & 16.8 & 25.6 & 26.1 \\
\hline Trade, finance & 13.9 & 24.8 & 27.9 \\
\hline Real estate & 8.9 & 14.0 & 18.0 \\
\hline Accommodation, food, tourism & 60.4 & 43.8 & 45.0 \\
\hline Health and social services & 18.8 & 24.0 & 15.3 \\
\hline Art, culture, communication & 35.6 & 36.4 & 45.9 \\
\hline Other services & 15.8 & 19.8 & 15.3 \\
\hline Active in two or more sectors (above) & 46.3 & 58.7 & 54.4 \\
\hline \multicolumn{4}{|l|}{ Focus * (a percent of SEs) } \\
\hline Employment & 30.7 & 50.4 & 45.0 \\
\hline Poverty & 42.6 & 61.2 & 57.7 \\
\hline Disability & 25.7 & 43.0 & 30.6 \\
\hline \multicolumn{4}{|l|}{ Mission ${ }^{* *}$ (a percent of SEs) } \\
\hline Mission focused & 67.3 & 54.5 & 51.4 \\
\hline Income focused & 9.9 & 11.6 & 12.6 \\
\hline Multipurpose & 22.8 & 33.9 & 36.0 \\
\hline
\end{tabular}

Notes: * Employment focus: social enterprise has employment/training purpose, or targets people with employment barriers. Poverty focus: social enterprise has an employment/training purpose, or targets people with employment barriers, or who are low income or homeless. Disability focus: serves those with physical, intellectual, and/or psychological disabilities.

${ }^{* *}$ Mission: three mutually exclusive categories to classify social enterprises based on their stated purposes:

- Income focused: defined as an organization with a singular purpose (income generation). These organizations may also combine income generation with up to two other purposes, whether it is an employment, social, cultural, or an environmental purpose. 


\section{Elson, Hall, Lesson-Klym, Penner, \& Andres (2015)}

- Mission focused: an organization with a social, cultural, and/or environmental focus and that has neither income generation nor employment as an additional focus.

- Multipurpose: an organization that has combined, multiple purposes, most often including the intent of creating employment opportunities.

\section{British Columbia social enterprise profile}

Our initial research findings from the 2014 Social Enterprise Sector Survey in BC indicate there may be over 1,000 social enterprises in the province, but this number was reduced to a list of 744 confirmed social enterprises after we conducted further screening to confirm if the organizations operated as social enterprises during the study period. We received responses from 163 of these social enterprises (for a valid response rate of 22 percent), but report the data from 121 respondents who provided sufficiently complete responses. As noted, the findings from $\mathrm{BC}$ and other provincial surveys cannot be considered a definitive reflection of all social enterprise sector activity in any particular province or territory.

\section{Social enterprise impact, $B C$}

Social enterprises engage people in multiple ways, unlike the more confined employee and client relationships in a traditional business. The same individual may have multiple, intersecting connections to a social enterprise, as member, recipient of training, employment, and services, or employee or volunteer:

- Social enterprises in $\mathrm{BC}$ have an average of 150 individual members and 14 organizational memberships. Overall, the responding social enterprises in BC total at least 17,800 individual members and 1,650 organizational memberships.

- Social enterprises provided paid employment for at least 1,900 workers (representing 944 full-time equivalent employees) in BC. This includes full-time, part-time, seasonal, and contract workers, who together earned over $\$ 37$ million in wages and salaries. Full-time, part-time, and seasonal workers represent an estimated 940 full-time equivalent employees (FTE). This represents almost \$40k per annum per FTE, although actual earnings per worker are about $\$ 19 \mathrm{k}$ per annum. The relatively high earnings of social enterprise employees in $\mathrm{BC}$ warrant further investigation.

- Those employed include 1,260 people who were employed as part of the mission of the social enterprise, such as those with disabilities and/or other employment barriers.

- Social enterprises also involved 4,700 full-time and part-time volunteers.

- In addition, social enterprises provided training to 4,640 people and provided services to over 860,000 people.

\section{Alberta social enterprise profile}

Like BC, this social enterprise sector survey is the third profile of social enterprises in Alberta, building on the previous report surveys completed in 2010 and 2012. Surveyed in 2014, the 101 responding enterprises in Alberta reported to have generated at least $\$ 57$ million in revenues, including at least $\$ 32$ million in sales in 2013. They paid at least $\$ 28$ million in wages and salaries to 3,590 employees (2,330 FTEs). They also trained 41,350 people, provided services to over 615,600 , and involved 9,480 volunteers.

Our initial research findings indicate there may be as many as 393 social enterprises in Alberta. This number was reduced to a list of 383 confirmed social enterprises after we conducted further screening to determine if organizations still operated as social enterprises. We successfully surveyed 117 of these social enterprises, for a valid response rate of 30.5 percent. 


\section{Elson, Hall, Lesson-Klym, Penner, \& Andres (2015)}

\section{Social enterprise impact, $A B$}

Social enterprises engage people in multiple ways, unlike the more confined employee and client relationships in a traditional business. The same individual may have multiple, intersecting connections to a social enterprise, as a member, recipient of training, employment, and services, or employee or volunteer.

Social enterprises in Alberta have an average of 68 individual members and 22 organizational memberships. Overall, the responding social enterprises in Alberta have at least 5,550 individual members and 1,860 organizational memberships.

Social enterprises provided paid employment for at least 3,590 workers in Alberta. This includes full-time, parttime, seasonal, and contract workers, who together earned at least $\$ 28$ million in wages and salaries. Full-time, part-time, and seasonal workers represent an estimated 2,330 full-time equivalent employees.

- Those employed include 3,190 people who were employed as part of the mission of the social enterprise, such as those with disabilities and/or other employment barriers.

- Social enterprises also involved 9,480 full-time and part-time volunteers.

- In addition, social enterprises provided training to 41,350 people and provided services to over 615,600 people.

\section{Manitoba social enterprise profile}

In 2013, the 125 responding enterprises in Manitoba reported to have generated at least $\$ 63.6$ million in revenues including donations and grant, and at least $\$ 49.3$ million in sales. They also trained 8,350 people, provided services to over 730,000 , and involved 6,840 volunteers.

\section{Social enterprise impact, MB}

- Social enterprises engage people in multiple ways, unlike the more confined employee and client relationships in a traditional business. The same individual may have multiple, intersecting connections to a social enterprise, as member, recipient of training, employment, and services, or employee or volunteer.

- Social enterprises in Manitoba have an average of 255 individual members and 7 organizational memberships. Overall, the responding social enterprises in Manitoba have at least 25,770 individual members and 705 organizational memberships.

- Social enterprises provided paid employment for at least 4,450 workers (1,780 FTEs) in Manitoba. This includes full-time, part-time, seasonal, and contract workers, who together earned at least $\$ 34.4$ million in wages and salaries. Full-time, part-time, and seasonal workers represent an estimated 1,780 full-time equivalent employees.

- Responding social enterprises reported that they had employed at least 3,550 people as a part of the mission, such as those with disabilities and/or other employment barriers in 2013.

- Social enterprises also involved 6,840 full-time and part-time volunteers.

- In addition, social enterprises provided training to 8,350 people and provided services to over 730,000 people. 


\section{Elson, Hall, Lesson-Klym, Penner, \& Andres (2015)}

\section{CONCLUSION}

This article has presented a partial profile of social enterprises in Western Canada. This picture is appropriately incomplete, but an accurate snapshot of the "state of the art" of this dynamic sector. No systematic survey of social enterprises has taken place in Saskatchewan, although one is planned. We certainly hope, over time, that a more robust picture will emerge, not only in Western Canada, but across Canada as a whole.

Meanwhile the available comparative statistics, profiles, and analysis provide a current profile of the impact of social enterprises in Western Canada, as reflected in Table 3, and elsewhere. The series of social enterprise sector surveys over the past six years in Western Canada - three in BC and Alberta and two in Manitoba-was initiated before the International Comparative Social Enterprise Models (ICSEM) project was launched. The surveys reveal important parallels and differences across Canadian provinces. The social enterprise sector surveys are designed as a community development tool. Each survey is undertaken only where we have been invited by leading social enterprise proponents within a particular province or territory to participate. It is a collaborative process and is designed to support the building of a more robust and productive social enterprise community.

The ICSEM Project is designed as a researcher-led project to identify and document different models of social enterprise across multiple countries. To this end, the three case study profiles in this article contribute to this international comparative analysis. There are some observations to be made based on our six years of experience working with social enterprise leaders across Canada. The first is that the evolution of social enterprises in Western Canada is driven by and through leaders at the community level. Governments and researchers are catching up to support actors in this play. The second is that the social enterprise sector survey demonstrates that the nonprofit form is a robust and appropriate corporate form to engage in an integrated blend of market activity and social, environmental, or cultural purposes. Third, there is scale to the impact of social enterprises. Not scale in the sense that enterprises get ever larger, although that may be the case in some instances, but scale in the sense that there is a collective impact of multiple social enterprises that can only been seen through surveys at a provincial level. This has been partially demonstrated in Table 3 , and more provincial surveys are planned in the year ahead. Finally, the most poignant contribution that social enterprises are making is not in their number, type, market share, or balance sheet, but in the lives of those they train and employ, and to whom they provide services.

\section{ACKNOWLEDGEMENTS}

The authors would like to express their appreciation to the organizations that supported this research, including the Institute for Community Prosperity, Mount Royal University, Simon Fraser University, enp Canada, Employment and Social Development Canada, and our fabulous community partners at enp BC, the Trico Charitable Foundation, and CCEDNet - Manitoba. We also appreciate the feedback received from the two anonymous reviewers.

\section{REFERENCES}

Alberta Human Services. (2015). Social innovation in Alberta. URL: http://socialpolicyframework.alberta.ca/SI [March 31, 2015]. 


\section{Elson, Hall, Lesson-Klym, Penner, \& Andres (2015)}

Bailey, L. (2015, April). Winnipeg's Neechi commons enlivens hope and possiblity for community. Enp newsroom (Axiom News and Enp-Canada), 32. URL: http://www.socialenterprisecanada.ca/en Inewsroom/service.prt?svcid=enp_newsroom1\&iddoc=373416\&page=newsDetail.tpt [March 31, 2015].

BC Partners for Social Impact. (2015). History. URL: http://www.hubcapbc.ca/BC-Partners-for-SocialImpact/BC-Partners-for-Social-Impact.aspx [March 10, 2015].

BC Social Innovation Council. (2012). Action plan recommendations to maximize social innovation in BC. Victoria, BC. URL: http://www.aletmanski.com/files/social-innovationbc-april-2012_c-2-1.pdf [March 10, 2015].

Brouard, F., \& McMurtry, J.J. (2015). Les enterprises sociales au canada: Un brief exposé. ANSERJ, 6(1), 17-23. coopzone. (2011). Neechi commons community business complex: Project profile. Winnipeg. URL: http://coopzone.coop/files/Project Profile.pdf [March 10, 2015].

Curtis, K. A. (2005). The comparative impact of welfare state restructuring on the nonprofit and voluntary sector in the US and Canada. In 34th Annual Conference, Association for Research on Nonprofit Organizations and Voluntary Action. Washington, DC.

Elson, P. R., \& Hall, P. V. (2012). Canadian social enterprises: Taking stock. Social Enterprise Journal, 8, 216236. doi:10.1108/17508611211280764

Elson, P. R., Hall, P. V., Leeson-Klym, S., Penner, D., \& Wamucii, P. (2015). 2014 Manitoba social enterprise sector survey report. Winnipeg.

enp Canada. (2015a). History of enp BC. URL: http://www.socialenterprisecanada.ca/en/communities/bc/ nav/history.html [March 10, 2015].

enp Canada. (2015b). Social enterprise manitoba. URL: http://www.socialenterprisecanada.ca/en/communities/ $\mathrm{mb}$ [March 31, 2015].

Government of Manitoba, \& Canadian Community Economic Development Network. (2015). Manitoba social enterprise strategy. Winnipeg, MB.

Howard, Hon. Jennifer. (2014). The 2014 Manitoba budget address. Winnipeg, MB. URL: http://www.gov.mb.ca/ finance/budget14/papers/speech14.pdf [May 21, 2015].

Kuterra. (2014). Out Story: Protecting the environment, improving farming. URL: http://www.kuterra.com/ourstory/ [May 21, 2015].

Living Oceans. (2015). Salmon farming. URL: http://www.livingoceans.org/initiatives/salmon-farming [May 20, 2015].

Loxley, J., \& Simpson, D. (2007). Government policies towards community economic development and the social economy in Quebec and Manitoba. Saskatchewan: Northern Ontario, Manitoba, and Saskatchewan Regional Node of the Social Economy.

Ministry of Finance. (2013). Community contribution companies. URL: http://www.fin.gov.bc.ca/prs/ccc/ [April 30, 2015].

Neechi Commons. (2015a). Investment shares. URL: http://neechi.ca/investment-share-offering/ [April 30, 2015].

Neechi Commons. (2015b). Neechi commons. URL: http://neechi.ca/neechi-commons/ [April 30, 2015].

Roach, R. (2006). The nonprofit and voluntary sector in Alberta: Regional highlights of the national survey of nonprofit and voluntary organizations. Toronto: Imagine Canada and Canada West Foundation.

Simard, C. (2010). The little store that could. Canadian Dimension, 16(4), 2. URL: http://search.proquest.com/ docview/204186118?accountid=1343 [April 30, 2015].

Social Enterprise Fund. (2015a). Building social entrepreneurs. URL: http://socialenterprisefund.ca/?page_id=28 [March 31, 2015].

Social Enterprise Fund. (2015b). How we help. URL: http://socialenterprisefund.ca/?page_id=14 [March 31, 2015]. 


\section{Elson, Hall, Lesson-Klym, Penner, \& Andres (2015)}

Sonpal-Valias, N., \& Sigurdson, L. (in press). Alberta's social policy: The neoliberal legacy of the Klein reforms. In P.R. Elson. (Ed.), Funding policies and the nonprofit sector in western Canada: Evolving relationships in a changing environment.

Statistics Canada. (2012). The Canadian population in 2011: Population counts and growth. Ottawa, ON: Ministry of Industry.

Strikwerda, E. (2014). The rise and fall of Alberta's welfare state: How social servics came and went. Albertaviews, 17(10), 30-35. URL: https://albertaviews.ab.ca/2014/11/25/the-rise-and-fall-of-albertaswelfare-state/ [March 31, 2015].

The Calgary Foundation. (2011a). Accelerating social enterprise growth in Calgary. Calgary, AB. URL: http:// calgary-foundation.s3.amazonaws.com/mercury_assets/127/original.pdf?1348013167 [March 31, 2015].

The Calgary Foundation. (2011b). Money \& mission: The emergence of social enterprise. Calgary, AB. URL: http://calgary-foundation.s3.amazonaws.com/mercury_assets/125/original.pdf?1348012805 [March 31, 2015].

United Way of Calgary and Area. (2014). Social enterprise in Canada: Research summary. Calgary, Alberta. URL: http://www.calgaryunitedway.org/main/sites/default/files/social_enterprise_in_calgary_research _summary.pdf [March 31, 2015].

\section{ABOUT THE AUTHORS / LES AUTEURS}

Peter R. Elson, PhD, is Senior Research Fellow at the Institute for Community Prosperity at Mount Royal University and Adjunct Assistant Professor in the School of Public Administration at the University of Victoria. Email: pelson@mtroyal.ca .

Peter Hall, PhD, is Associate Professor in the Urban Studies program at Simon Fraser University. Email: pvhall@sfu.ca .

Sarah Leeson-Klym is Manitoba Regional Director at the Canadian CED Network. Email: sleesonklym @ccednet-rcdec.ca .

Darcy Penner is Social Enterprise Policy \& Program Co-ordinator at the Canadian CED Network (Winnipeg office).Email: d.penner@ccednet-rcdec.ca .

Jill Andres is Changemaker in Residence at the Institute for Community Prosperity at Mount Royal University. Email: jandres@mtroyal.ca . 